\title{
Exchange Rate and Trade in Services Nexus in Nigeria: A Non-Linear ARDL Approach
}

\author{
By Nathan Audu* and Titus Obiezue
}

\begin{abstract}
A nonlinear ARDL model is employed to investigate the asymmetric drivers of non-oil trade in services between Nigeria and Netherlands. A significant number of past studies have concentrated their attention on the elasticity of trade in services to real exchange rates and income as well as on non-oil export, total export trade or import, yet none have delve into asymmetric relationship. This study aims to fills this void. Our result shows that the effects of exchange rate variations have both positive and negative displays with more negative asymmetry. This provides further insights in the nature of service asymmetries.
\end{abstract} (JEL Codes: C22, D43, E31, L71, Q41)

Keywords: asymmetric cointegration, exchange rate adjustment, disaggregated, services

\section{Introduction}

The link between foreign exchange rates and trade in services has captured the interest of both policy makers and investors as services play a vital role in the development of an economy. Services contribute significantly to global gross domestic product (GDP) as a more efficient services sector promotes economic growth both directly and indirectly via spillover effects. For instance, in 2017 it accounted for over $63 \%$ of global GDP and more than $35 \%$ to Nigeria's GDP. However, the contribution of services in international trade remains very poor as the country's international trade is dominated by the export of merchandise goods. In 2018 crude oil export contributed $92.6 \%$ of total foreign exchange. Thus, services sector's contribution to total export and foreign exchange is insignificant.

This study has become important because of the peculiarities of the Nigeria policy environment. For instance, Nigeria is net importer of international services, which has increased the burden payments for travels, transportation and other business services. Available data from NBS (2018) also indicates that the Netherlands was Nigeria's highest non-oil trading partner accounting for over $18.8 \%$ of total non-oil exports. Nigeria's major import from the Netherlands include higher education services, travels, other business services, frozen fish, petroleum oils and engines \& motor parts; while the major export to the Netherlands include crude oil, cocoa beans, cocoa cake, cocoa butter, frozen shrimps and crabs, dried split ginger, and cashew kernel. There is, therefore, a major scope to boost services trade with major trading partners, especially the Netherlands, as the country has been a net importer of services and a net exporter

\footnotetext{
*Nigeria Country Economist, West African Monetary Institute, Ghana.

${ }^{ \pm}$Senior Supervisor, Research Department, Central Bank of Nigeria, Nigeria.
} 
of primary commodities. Studies that clarify our understanding of the exchange rate drivers of trade in services in Nigeria are extremely important. This is extremely important for trade in service literature and exchange rate policy.

Following the introduction of the Structural Adjustment Programme (SAP) in 1986, Nigeria reformed its foreign exchange system, trade policies, and business and agricultural regulations. The adoption and implementation of the neo-liberal policies of the SAP in many African countries between the 1980s and 1990s truncated and stagnated the pace and pendulum of economic growth and development in the continent. As a matter of fact, many countries were stuck in a debt trap at the end of the 1990s. This situation had been exacerbated by SAPs. The SAP policies of deregulation and privatization worsened the unemployment crisis which had reached a crisis point by the mid-1980s. Their reform was illconceived and unsuitable for African economics considering its poor volatility and skewed structure and form. In the past years, we have seen a debt-trap scenario in Greece. After ten years of crisis, conditionalities, bailouts and insufficient debt relief, EU lending countries seriously consider demanding that Greece generate budget surpluses until the year 2060 so it can service its debt. Clearly, the core of Nigeria's SAP is a radical reform of trade and exchange rate policies combined with enhanced market liberalization measures and institutional changes to create a degree of economic flexibility which would enhance the effectiveness of the incentive system.

Even though the liberalisation of the exchange rate promoted economic growth and development, it also contributed to exchange rate volatilities. Evaluating the asymmetry effects of exchange rate volatilities and using a nonlinear model is perhaps the direction of current and future economic research. In particular, Bussiere (2013) in assessing the pass-through effect of exchange rate volatility to import and export prices found an asymmetric relationship. Exchange rate volatilities impact on traded goods' prices in an asymmetric manner and on trade itself which finally impact on the trade balance. Secondly, Bahmani-Oskooee and Fariditavana (2016) employed the non-linear ARDL approach to evaluate the J-Curve phenomenon and found more evidence of the J-curve supporting nonlinear adjustment of variables as well as asymmetric effects of exchange rate changes on the trade balance, using bilateral trade balance models of the U.S. with each of her six largest trading partners.

This paper contributes in two ways. First, it confirms asymmetric effects of exchange rate volatilities on bilateral trade balances on three service sectors between Nigeria and Netherlands. The Netherlands tops the list of Nigeria's nonoil traders with about $20 \%$. Secondly, it employed the a generalized NARDL model, which distinguishes small to large volatilities in exchange rate change and captures nonlinear exchange rate effects between Nigeria and Netherlands with greater precision than the more common two-way decomposition of appreciation and depreciation. 


\section{Empirical Literature on Trade in Services and Exchange Rate}

Large volume of literature on exchange rate volatility and trade in service exist and discussions are ongoing. Pattichis (2012) used disaggregated data on US - UK trade to investigate the effects of exchange rate depreciation on trade in services both in the short-and long-run. The study focused on travel, passenger fares and other transportation services and employs the ARDL approach. The results reveal that the real exchange rate has a statistically significant effect on trade in services in at least one of the time periods. Similarly, Mallick (2012) carried out a comparative empirical analysis of the role of exchange rate on services and goods exports. The study finds that while depreciation of exchange rate encourages services exports, it discourages goods exports. The finding suggests that depreciation of currencies strategy has a greater potential for the poor economies to gain from their exports.

Baggs et al. (2010) analyse the effects of industry specific real exchange rate movements on the profitability, survival, and sales of Canadian service sector firms. The study show significant exchange rate effect on service firms that is qualitatively similar to that found for manufacturing firms. Employing a VAR model to investigate the exchange rate propagation mechanisms to real exports of U.S. services and agricultural sectors on monthly data from 1992:1 to 2009:12, Ojede (2015) found that exchange rate shocks impact services exports more than they do on agricultural exports. However, Ketenci and Uz (2010) empirical findings revealed that the real exchange rate is not a significant determinant for the trade in services. Other studies such as Prieto et al. (2011) revealed that internet penetration is a significant determinant of trade in services in the importing country as opposed to the exporter.

Utilizing traditional and recent models of import and export demand functions Moshirian (2007) estimated the determinants of trade flows for two service industries, travel and passenger transportation services for 16 Organisation for Economic Co-operation and Development (OECD) countries. The empirical results indicate similarity between trades in goods and trade in services. Also, Khan et al. (2014) employed GARCH-based exchange rate volatilities and the least-squares dummy variable technique with fixed-effects estimation to measure the volatility impact on both demand functions with reference to Pakistan's trading partners. The results show that, when Pakistan employed the US dollar as the vehicle currency with its trading partners, volatility discouraged both imports and exports.

It is therefore obvious from the literature that the impact of exchange rate volatility on trade in services vary across countries and services sector. Babatunde (2016) estimated the elasticity of trade in services to real exchange rates and income in Nigeria. Adopting the imperfect substitute's model, the empirical findings revealed an inelastic real exchange rate and income elasticities in export and import of services functions in the long and short run. In his work, Aliyu (2010) used the VECM and the VAR model to analyse the impact of exchange rate volatility on Nigeria's non-oil exports. The result established a long-run stable and negative relationship between Naira exchange rate volatility and non-oil 
exports in Nigeria. In the alternative, the result was positive for the US Dollar exchange rate volatility and non-oil exports.

Dickson and Andrew (2013) using the error correction and GARCH models investigated the impact of exchange rate fluctuations on trade variations in Nigeria. The result of the study had it that exchange rate volatility is not significant in explaining variations in import but it was found to be statistically significant and positive in accounting for variations export. In the same vein, Aliyu and Tijjani (2015) empirically examine the long-run pass through of the official exchange rates into trade balance in Nigeria by means of threshold cointegration and asymmetric error correction modeling. The estimated asymmetric ECM provide new evidence for slower transmission of exchange rate depreciations into the country's trade balance, which in turn appears to offer partial support for the Dutch disease hypothesis.

Imoughele and Ismaila (2015) investigated the impact of exchange rate on non-oil export in Nigeria. They applied Johansen's co-integration test to establish both the short and long run relationship between non-oil exports and the independent variables. The OLS result showed that effective exchange rate, money supply, credit to the private sector and economic performance have a significant impact on the growth of non-oil export, while appreciation of exchange rate has negative effect. Using the same methodology, Abogan et al. (2014) investigated the impact of non-oil export on economic growth in Nigeria. They found that the impact of non-oil export on economic growth was moderate. From the above, it is clear that apart from Babatunde (2016) who estimated the elasticity of trade in services to real exchange rates and income, other studies in Nigeria have focused on the impact of exchange rate on non-oil export, total export trade or import. This study fills the gap by investigating the asymmetry effects of exchange rate volatilities on bilateral trade balances of Nigeria with the Netherlands.

\section{Model Specification and Data Description}

To moderate the likely risk of aggregation bias and to capture the sub-sectoral effects which may occur at the service level, demand for travels (TRV), transportation (TRN) and other business services (OBS) trade in services is specified based on the top three NBS services groupings. We opted for TRV, TRN and OBS because they constitute over $85 \%$ of trade balance in Nigeria. Also, available data from NBS (2018) indicated that the highest ten trading partners in descending other in oil and non-oil shows that Netherlands (oil) and Netherland (non-oil) accounts for $15.2 \%$ and $18.8 \%$, respectively. Chiu et al. (2010) investigated the nexus between real exchange rate and trade balance. They employed Rose and Yellen, (1989) the reduced form equation with similar countries. Their result revealed that the impact of trade balance depends on the real exchange rate as well as the incomes of both the domestic and foreign economies. Thus, in the case of Netherland (non-oil) and Nigeria trade, the relationship for each grouping of service $i$ is represented by an algebraic function thus:

$$
T B A L_{i, t}=f(B D C, G D P N e t h e r l a n d, G D P N i g e r i a)
$$


where $\mathrm{TBAL}_{\mathrm{i}, \mathrm{t}}$ equals trade balance of grouping I, which defines Nigerian non-oil exports to Netherlands divided by Nigerian imports from Netherlands in that grouping; Average bureau de change exchange rate is the real exchange bilateral rate in US dollars between Nigeria, Netherlands, hence, an increase connotes a depreciation of the naira and vice versa. GDP-Netherland and Nigeria, is the nominal GDP of both countries, respectively. All variables except TBAL are in logarithmic form.

The foregoing argument in equation (1) is symmetrical, thus, our disaggregated model follows an eclectic Shin et al. (2014), Atil et al. (2014) and Kilian et al. (2011) methodology to inspect the asymmetric effect of nominal exchange rate on trade in services as shown in equations (2) and (3).

$$
\begin{gathered}
\omega_{i}=\gamma_{10}+\sum_{k=1}^{\alpha} \gamma_{11}, k^{i} t-k \\
+\sum_{k=1}^{\alpha} \gamma_{12}, k^{\pi} t-k+\mu_{1, t}, \quad \text { where } t=1,2, \ldots ., T \\
\pi_{i}=\gamma_{20}+\sum_{k=1}^{\alpha} \gamma_{21}, k^{i} t-k \\
+\sum_{k=1}^{\alpha} \gamma_{22}, k^{\pi} t-k+\mu_{1, t}+\sum_{k=1}^{\alpha} \lambda_{21}, k^{\pi^{+}} t-k+\mu_{2, t} \text { where } t \\
=1,2, \ldots ., T
\end{gathered}
$$

where $\alpha=$ lag order, $\mathrm{i}_{\mathrm{t}}=$ change in exchange rate and $\pi_{\mathrm{t}}=$ column vector of macroeconomic variables: exchange rate and output. The linear symmetric model of $i_{t}$ and $\pi_{t}$ is represented in equation (2), while in equation (3), we included exchange rate change and a censored variable $\mathrm{i}_{\mathrm{t}}$ or $\left(\mathrm{i}_{\mathrm{t}}^{+}\right)$. The $\mathrm{i}_{\mathrm{t}}^{ \pm}$variable depicts the positive and negative changes in exchange rate, as presented in equation (4):

$$
\begin{aligned}
& i_{t}^{+}=\left\{\begin{array}{l}
i_{t}, \text { if } i_{t}>0 \\
0, \quad \text { if } i_{t} \leq 0
\end{array}\right. \\
& i_{t}^{-}= \begin{cases}i_{t}, & \text { if } i_{t}<0 \\
0, & \text { if } i_{t} \geq 0\end{cases}
\end{aligned}
$$

The coefficient $\gamma_{10}$ and $\gamma_{20}$ in equations (2) and (3) represents the intercept term of column vector. Similarly, $\gamma_{11}$ and $\gamma_{21}$, symbolizes the coefficients of the exchange rate change. The value $\gamma_{12}$ and $\gamma_{22}$ is the matrix of macroeconomic variables. $\lambda_{21}=$ censored variable column vector coefficient. $\mu_{1, t}$ and $\mu_{2, t}$ are the residual vectors.

\section{Data Description Fluctuation}

From Figure 1, we presented graphs ( $a, b, c, d$, e and f) for trend analysis at levels for the variables in our model: ratios of trade balance for Travels, Transportation, Other business services, Bureau de Change exchange rate as well as Netherlands and Nigeria nominal gross domestic product, respectively. We graphed and the outcome is presented in Figure 1. The evaluation of Figure 1a, reveals that the element of the ratio of Nigeria's exports to Netherlands over Nigeria's imports from Netherlands on travels (TBTRVNN) exhibits a continuous 
variability with the lowest ebb in 2018Q1 and has a deterministic trend in the oscillation while Figure $1 \mathrm{~b}$ showed that the ratio of Nigeria's exports to Netherlands over Nigeria's imports from Netherlands on transportation (TBTRNNN) unveils a endless cyclical fluctuation with the lowest recede in 2014Q4 and a deterministic trend in the variation.

Figure 1. Quarterly Macroeconomic Sample from 2008:1 to 2019:2
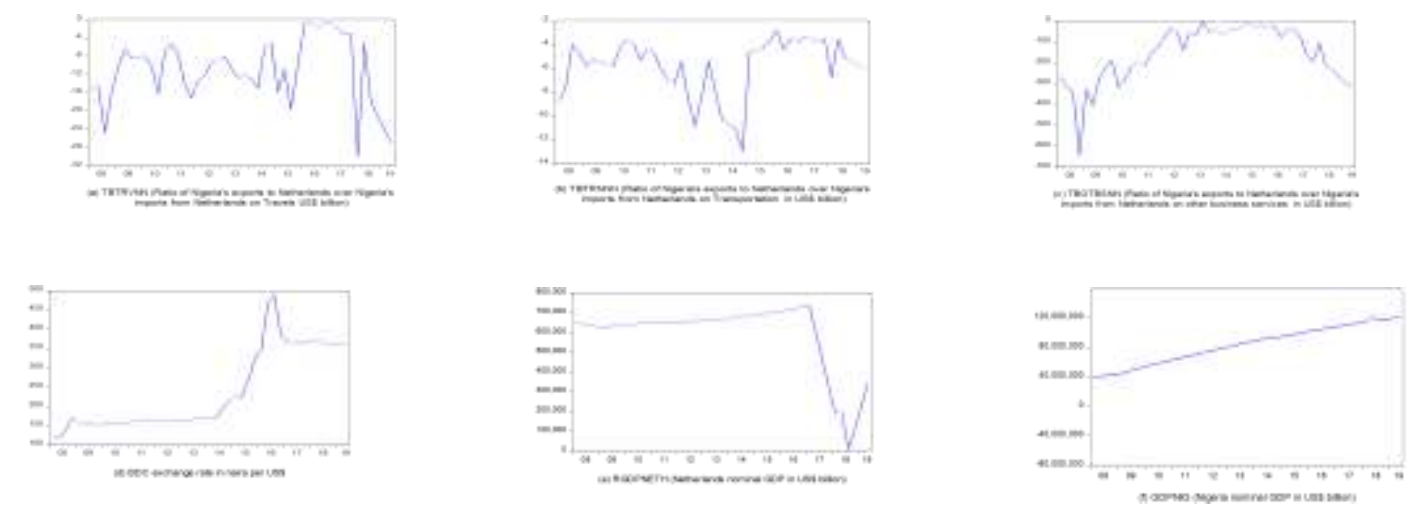

Figure 1c, indicated that it has a humped shaped instability but showed a major downward break around 2008Q4 and this could be attributed to the 2008 global financial crisis while Figures $1 \mathrm{~d}-\mathrm{BCD}$ exchange rate exhibited element of minor break in 2016Q3 as result of the shift to a more flexible exchange rate regime. Similarly, Figures 1e - Netherlands nominal GDP and 1f - Nigeria's nominal GDP, demonstrated rectilinearly upward with a deterministic trend in the pattern. Also, graphs e and f, reveal that the gross domestic product (GDP) of Netherlands and Nigeria maintained a steady growth throughout the period. The GDP of Netherlands grew from US $\$ 563.011$ million to US $\$ 1.88$ billion from 2008Q1 to 2018Q2, it is an increase of about 70\%. Similarly, the GDP of Nigeria grew from US\$391.5 million to US\$1.21 billion from 2008Q1 to 2018Q2, it represents an increase of about $68 \%$.

\section{Analysis}

The evaluation of the asymmetric influence of trade in services on exchange rate, a reduced-form equation was estimated which was derived from a simple dual country (Nigeria and Netherlands) model of trade harkened to Rose and Yellen (1989) using quarterly series spanning 2008Q1 to 2018Q4. The factors used in our VAR model included trade in services, exchange rate (BDC), foreign output (The Netherlands), domestic output (Nigeria). The BDC exchange rate represents the value of the naira in the basket, comprising 0.5US\$ + 0.5EUR. Output is nominal gross domestic product. All the parameters employed in this study are in their natural logarithms. 
We conducted summary statistics, correlation matrix and other preliminary tests for all the series as shown in Tables 1, 2 and 3, respectively. The summary statistics in Table 1 provides information about the mean, range, standard deviation, skewness, kurtosis and Jarque-Bera statistics, respectively. The average of Nigerian trade balance (Travels - TBTRVNN, Transportation - TBTRNNN and Other business services -TBOTBSNN), the logarithms of Bureau de Change exchange rate (LBDC), The Netherlands's nominal GDP (LRGDPNeth) and Nigeria's nominal GDP (LGDPNig) were $-11.11,-5.89,-160.92, \$ 236.13$, US\$589,144.10 million and US\$83,321,717.00 million, respectively.

Table 1. Summary Statistics

\begin{tabular}{|l|c|c|c|c|c|c|}
\hline Statistics & Tbtrvnn & Tbtrnnn & Tbotbsnn & Bdc & Gdpneth & Gdpnig \\
\hline Mean & -11.11 & -5.89 & -160.92 & 236.13 & 589144.10 & 83321717.00 \\
\hline Median & -10.29 & -5.38 & -134.81 & 169.50 & 651336.60 & 86714353.00 \\
\hline Maximum & -0.80 & -2.82 & -5.00 & 490.00 & 737048.00 & 121000000.00 \\
\hline Minimum & -29.86 & -12.98 & -640.69 & 119.00 & 10315.33 & 39157884.00 \\
\hline Std. Dev. & 7.13 & 2.42 & 134.27 & 105.01 & 177615.60 & 25509685.00 \\
\hline Skewness & -0.61 & -1.18 & -1.12 & 0.79 & -1.97 & -0.22 \\
\hline Kurtosis & 3.00 & 3.68 & 4.60 & 2.16 & 5.62 & 1.80 \\
\hline Jarque-Bera & 2.88 & 11.64 & 14.52 & 6.19 & 43.01 & 3.13 \\
\hline Probability & 0.24 & 0.00 & 0.00 & 0.05 & 0.00 & 0.21 \\
\hline
\end{tabular}

The series range (maximum and minimum) values were -0.80 and -29.86 for TBTRVNN, -2.82 and -12.98 for TBTRNNN, -5.00 and -640.69 for TBOTBSNN, $\$ 490$ and $\$ 119.00$ for LBDC, US\$737,048.00 million and US\$10,315.33 million for LGDPNeth, US\$121,000,000.00 million and US $\$ 39,157,884.00$ million for LRGDPNIG with the highest standard deviation of US $\$ 25,509,685.00$ million for GDPNig, US $\$ 177,615.60$ million for GDPNeth, 134.27 for TBOTBOBSNN, 105.01 for BDC, followed by 7.13 (TBTRVNN), while the standard deviation of 2.42 for TBTRNNN, respectively.

The evidence of a positive skewness exist in the statistical distribution of Bureau De Change exchange rate, thus, inferring that the variable is extreme right tailed. Conversely, TBTRVNN, TBTRNNN, TBOTBSNN, GDPNeth and RGDPNig possesses a small and negative skewness statistics (i.e., leptokurtic), thus, signifying the presence of a left tail. However, the kurtosis which measures peakedness and tailedness of a normal series indicated that all the variables are highly peaked as well as platykurtic than normal distribution except BDC and GDPNig which are less than 3, thus, indicating that the series is reasonably peaked and mesokurtic. The Jarque-Bera (JB) which employs the evidence from skewness and kurtosis to validate normality confirms normality for all the series shows that all the series are normality distributed. 
Table 2. Correlation Matrix

\begin{tabular}{|c|c|c|c|c|c|c|}
\hline $\begin{array}{l}\text { \{Correlation\} } \\
\text { [t-Statistics] } \\
\text { (Probability) }\end{array}$ & TBTRVNN & TBTRNNN & TBOTBSNN & $\mathrm{BDC}$ & GDPNETH & GDPNIG \\
\hline TBTRVNN & 1 & & & & & \\
\hline TBTRNNN & & 1 & & & & \\
\hline TBOTBSNN & & & 1 & & & \\
\hline & & & & & & \\
\hline \multirow{3}{*}{$\mathrm{BDC}$} & $\{0.1693\}$ & $\{0.4282\}$ & $\{0.2245\}$ & \multirow{3}{*}{1} & & \\
\hline & [1.1392] & [3.1433] & {$[1.5281]$} & & & \\
\hline & $(0.2608)$ & $(0.0030)$ & $(0.1336)$ & & & \\
\hline \multirow{3}{*}{ GDPNETH } & & & & & \multirow{3}{*}{1} & \\
\hline & $\{0.4381\}$ & $\frac{\{-0.1233\}}{\Gamma-08245]}$ & $\{0.3126\}$ & $\{-0.4397\}$ & & \\
\hline & $(0.0023)$ & $(0.4141)$ & $(0.0344)$ & $(0.0022)$ & & \\
\hline & & & & & & \\
\hline \multirow{3}{*}{ GDPNIG } & $\{0.0408\}$ & $\{0.1187\}$ & $\{0.4967\}$ & $\{0.8321\}$ & $\{-0.4776\}$ & \multirow{3}{*}{1} \\
\hline & {$[0.2709]$} & {$[0.7931]$} & [3.7963] & [9.9530] & {$[-3.6059]$} & \\
\hline & $(0.7877)$ & $(0.4320)$ & $(0.0004)$ & $(0.0000)$ & $(0.0008)$ & \\
\hline
\end{tabular}

Table 2 presents correlation summaries for the three models at 5 per cent significant levels. The result indicated that the relationship between TBTRVNN and BDC, GDPNig; between TBTRNNN and GDPNig as well as between TBOBSNN and BDC where positive but insignificant while that of TBTRNNN and GDPNeth was also insignificant and negative. Table 2 also shows a significant positive association (0.44) of TBTRVNN and GDPNeth. These results confirmed the import dependent nature of the Nigerian economy. The result from Table 2 reveals a significant positive association (0.43) of TBTRNNN and BDC. These results confirmed that most Nigerian source for their dollar from the parallel market when traveling abroad. A moderate significant positive correlation of 0.31 and 0.50 exists between TBOTBSNN and GDPNeth and GDPNig, respectively. This confirms that both Netherlands and Nigeria benefit from transportation services. A very high positive significant relationship of 0.83 exists between BDC and GDPNig. This confirms that appreciation of the naira to US dollar is more beneficial to the Nigerian economy. A moderate significant negative correspondence of 0.44 and 0.48 exist between BDC and GDPNeth as well as between GDPNeth and GDPNig, respectively. This confirms that trade in service between Netherlands and Nigeria is negatively skewed in-favour of Netherlands than Nigeria. 
Table 3. Unit Root Test

\begin{tabular}{|l|c|c|c|c|c|}
\hline \multirow{2}{*}{ Variables } & \multicolumn{2}{|c|}{ Phillip-Perron (PP) } & \multicolumn{2}{c|}{ NG-Perron (NP) } & \multirow{2}{*}{ Decision } \\
\cline { 2 - 5 } & Level & $1^{\text {st }}$ Diff & Level & $1^{\text {st }}$ Diff & \\
\hline TBTRVNN & -3.720 & -11.501 & -2.707 & -2.980 & $\mathrm{I}(0)$ \\
\hline TBTRNNN & -3.074 & -8.342 & -2.259 & -3.284 & $\mathrm{I}(0)$ \\
\hline TBOTBSNN & -1.814 & -10.398 & -1.772 & -3.105 & $\mathrm{I}(1)$ \\
\hline LBDC & -0.925 & -4.948 & -0.692 & -3.192 & $\mathrm{I}(1)$ \\
\hline LGDPNeth & -1.216 & -3.824 & -1.311 & -0.546 & $\mathrm{I}(1)$ \\
\hline LGDPNig & -2.343 & -8.856 & -12.37 & -3.206 & $\mathrm{I}(0)$ \\
\hline
\end{tabular}

Reference: Findings of Research

Our VAR model requires that the series must be stationary. To ascertain the used Phillip-Perron (PP) and NG-Perron (NP) unit root tests is shown in Table 3. The preliminary test result in Table 3 reveals that the null hypothesis of unit root was accepted for TBTRVNN, TBTRNNN and GDPNig in levels while all other series were reject the null hypothesis of unit root at first differences. In the light of the above result, it was inferred that the data were $\mathrm{I}(0)$ and $\mathrm{I}(1)$. This means that our autoregressive distributed lag (ARDL) model can be employed satisfactory. Also, except TBTRVNN, TBTRNNN and GDPNig, all other variables enter into the analysis in their levels. The study used the Akaike, Schwarz and HannanQuinn information criterion which selected lag order 2 and 1, respectively, was selected in the three models as shown in Table 4.

Table 4. Lag Selection Criteria

\begin{tabular}{|l|c|c|c|c|c|c|}
\hline \multicolumn{7}{|c|}{ Travels } \\
\hline Lag & LogL & LR & FPE & AIC & SC & HQ \\
\hline 0 & 90.07 & NA & 1.42 & -4.41 & -4.24 & -4.35 \\
\hline 1 & 357.11 & 465.6 & 3.67 & -17.29 & -16.43 & -16.98 \\
\hline $\mathbf{2}$ & $\mathbf{3 9 7 . 2 6}$ & $\mathbf{6 1 . 7 7 ^ { * }}$ & $\mathbf{1 . 0 9}$ & $\mathbf{- 1 8 . 5 2}$ & $\mathbf{- 1 6 . 9 9 *}$ & $\mathbf{- 1 7 . 9 8 ^ { * }}$ \\
\hline 3 & 416.77 & 26.02 & $9.82^{*}$ & $-18.71^{*}$ & -16.49 & -17.91 \\
\hline \multicolumn{7}{|c|}{ Transportation } \\
\hline 0 & 151.52 & NA & 0.00 & -7.57 & -7.39 & -7.50 \\
\hline 1 & 416.54 & 462.09 & 0.00 & -20.34 & $-19.48^{*}$ & -20.03 \\
\hline $\mathbf{2}$ & $\mathbf{4 4 3 . 4 1}$ & $\mathbf{4 1 . 3 4}$ & $\mathbf{1 . 0 3} *$ & $\mathbf{- 2 0 . 8 9 *}$ & $\mathbf{- 1 9 . 3 6}$ & $\mathbf{- 2 0 . 3 4}$ \\
\hline 3 & 449.51 & 8.14 & 0.00 & -20.39 & -18.17 & -19.59 \\
\hline \multicolumn{7}{|c|}{ Other Business Services } \\
\hline 0 & 168.95 & NA & 2.49 & -8.46 & -8.29 & -8.40 \\
\hline $\mathbf{1}$ & $\mathbf{4 2 7 . 6 1}$ & $\mathbf{4 5 1 . 0 0}$ & $\mathbf{9 . 8 7}$ & $\mathbf{- 2 1 . 9 0 *}$ & $\mathbf{- 2 0 . 0 5 *}$ & $\mathbf{- 2 0 . 6 0 *}$ \\
\hline 2 & 447.03 & $29.87^{*}$ & $8.52^{*}$ & $-21.08^{*}$ & -19.54 & -20.53 \\
\hline 3 & 458.61 & 15.45 & 1.15 & -20.85 & -18.63 & -20.06 \\
\hline
\end{tabular}

The AR Roots Table and AR Roots graph for Travels, Transportation and Other Business Services in Table 3 and Figure 2, respectively, indicated that all the VAR models are stable. All the data series used in this study were retrieved from the International Financial Statistics (IFS) and national Bureau of Statistics (NBS), the electronic data base of the Central Bank of Nigeria (CBN). 
Table 5. Roots of Characteristic Polynomial

\begin{tabular}{|c|c|c|c|c|c|}
\hline \multicolumn{2}{|c|}{ Travels } & \multicolumn{2}{c|}{ Transportation } & \multicolumn{2}{c|}{ Other Business Services } \\
\hline Root & Modulus & Root & Modulus & Root & Modulus \\
\hline 0.9906 & 0.9906 & 0.9964 & 0.9964 & 0.9943 & 0.9943 \\
\hline 0.9523 & 0.9523 & 0.9632 & 0.9631 & 0.9585 & 0.9585 \\
\hline 0.8187 & 0.8187 & 0.7771 & 0.7771 & 0.7754 & 0.7754 \\
\hline 0.1807 & 0.1807 & 0.1947 & 0.1947 & -0.0229 & 0.0229 \\
\hline
\end{tabular}

Note: No root lies outside the unit circle. VAR satisfies the stability condition.

Figure 2. Inverse Roots of AR Characteristic Polynomial for VAR Stability

A: Travels

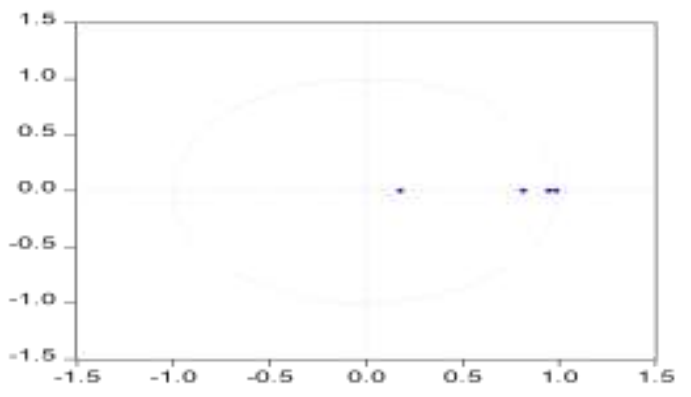

B: Transportation

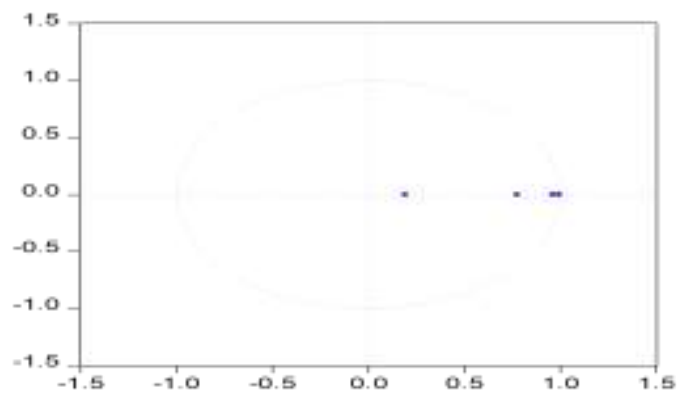

C: Other Business Services

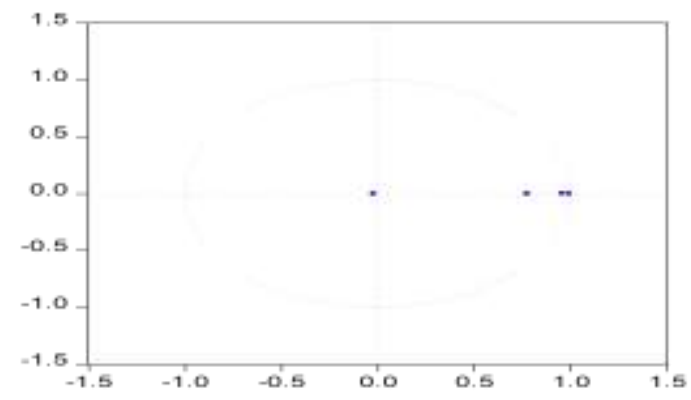

We conducted test for the existence of either symmetry or asymmetry in our model. To ascertain this we adopted the bounds test for linear and non-linear cointegration tests as shown in Table 6 . The linear and non-linear bounds test result in Table 6, shows that the two key variables have an asymmetric effect on each other in the long-run form models for both the linear and non-linear form specification, since the calculated F-statistics value are greater than both the lower and upper critical bound values at the $5 \%$ significant level, thus, signifying the existence of cointegration. The linear and non-linear results reveal that an incorrect model specification would lead to an unreliable conclusion vis-à-vis whether the selected macroeconomic variables co-move in the same direction in the long run or not.

We employed the general-to-specific methodology to evaluate the non-linear model in equations (2), (3) and (4). The results are presented in Tables 7, 8 and 9, respectively. The model allows us to gauge the dynamics in balance of travels, transportation and other business services and their reaction to the selected macroeconomic variables, positive (POS) and negative (NEG) changes in the nominal naira exchange rates. To validate the finding in our long-run equation, we 
conducted various diagnostic tests to ascertain the efficacy of the adjusted Rsquare in the dynamic model and the various outcomes are presented in Table 7. Given the adjusted R-squared value of about $0.82,0.57$ and 0.55 , respectively, indicates the existence of a high explanatory command of the regressors in explaining changes of the regressands.

Table 6. Bounds Test for Linear/Nonlinear Cointegration

\begin{tabular}{|c|c|c|c|c|}
\hline \multicolumn{5}{|c|}{ A: Travels Model } \\
\hline Model & \multirow{2}{*}{ F-statistics } & \multicolumn{2}{|c|}{ Bounds } & \multirow{2}{*}{ Conclusion } \\
\hline specification & & Lower & Upper & \\
\hline Linear & 6.71 & 2.79 & 3.67 & Cointegration \\
\hline Non-linear & 11.38 & 2.56 & 3.49 & Cointegration \\
\hline \multicolumn{5}{|c|}{ B: Transportation Model } \\
\hline Model & \multirow{2}{*}{ F-statistics } & \multicolumn{2}{|c|}{ Bounds } & \multirow{2}{*}{ Conclusion } \\
\hline specification & & Lower & Upper & \\
\hline Linear & 4.29 & 2.79 & 3.67 & Cointegration \\
\hline Non-linear & 4.05 & 2.56 & 3.49 & Cointegration \\
\hline \multicolumn{5}{|c|}{ C: Other Business Services Model } \\
\hline Model & \multirow{2}{*}{ F-statistics } & \multicolumn{2}{|c|}{ Bounds } & \multirow{2}{*}{ Conclusion } \\
\hline specification & & Lower & Upper & \\
\hline Linear & 7.58 & 2.79 & 3.67 & Cointegration \\
\hline Non-linear & 7.13 & 2.56 & 3.49 & Cointegration \\
\hline
\end{tabular}

Note: $5 \%$ level of significance. The optimal lag order were based on SIC for A and AIC for B and C.

Table 7. Diagnostics

\begin{tabular}{|c|c|c|c|}
\hline \multirow{3}{*}{ Test } & \multicolumn{3}{|c|}{ Dependent Variables } \\
\hline & Travels & Transportation & Other Business Services \\
\hline & Statistics & Statistics & Statistics \\
\hline Serial correlation LM tests & $\begin{array}{c}1.2007 \\
(0.4119)\end{array}$ & $1.2332(0.3062)$ & $0.4489(0.6421)$ \\
\hline Heteroskedasticity ARCH test & $\begin{array}{c}3.5421 \\
(0.8366) \\
\end{array}$ & $0.0844(0.7731)$ & $\begin{array}{c}0.0228 \\
(0.8807)\end{array}$ \\
\hline Normality test: Jarque-Bera & $\begin{array}{c}7.0447 \\
(0.5189) \\
\end{array}$ & $0.8161(0.6649)$ & $9.6450(0.8732)$ \\
\hline Ramsey RESET test & $\begin{array}{c}3.0652 \\
(0.1866)\end{array}$ & $\begin{array}{c}1.7991 \\
(0.1338)\end{array}$ & $\begin{array}{c}0.6229 \\
(0.7104)\end{array}$ \\
\hline CUSUM & Stable & Stable & Stable \\
\hline CUSUM sum of squares & Stable & Stable & Stable \\
\hline R-squared & 0.8551 & 0.6025 & 0.5913 \\
\hline Adjusted R-squared & 0.8211 & 0.5749 & 0.5597 \\
\hline
\end{tabular}

Note: Probability values of the respective tests are shown in brackets.

More so, the serial correlation LM test and the heteroskedasticity ARCH test show the absence of serial correlation in the residuals and that the residuals have constant variance overtime. Also, the Jarque-Bera test and Ramsey RESET tests, respectively, discloses that the error of variables are normally distributed and the 
model is properly specified while the CUSUM and CUSUM of squares tests shows that the model is stable since the appraised model lies within the 5 per cent bound. In all the tests, the null hypothesis indicates that there is no serial correlation, no heteroscedasticity, and normally distributed errors. The three models passed all the diagnostic tests as presented in Table 7 as all the p-values exceed the various 5 percent levels of significance.

Short-run and long-run results are presented in Tables 8 and 9. The results in Tables 8 and 9, reveals that all the parameters conform to a priori expectation both in the short- and long- run. The short-run result in Table 8 shows that the first lag of travels, transportation and other business services except TBOBTSNI was positive but only significantly impacted on the current TBTRVNN.

Table 8. NARDL Short-Run Results

\begin{tabular}{|l|c|c|c|c|}
\hline A: Travels & Coefficient & Std. Error & t-Statistic & Prob. \\
\hline Travels & 0.2655 & 0.1153 & 2.3035 & 0.0084 \\
\hline TBTRVNN(-1) & 0.1018 & 0.0142 & 7.1889 & 0.0000 \\
\hline$\Delta$ LBDC_POS & 2.6283 & 0.6534 & 4.0223 & 0.0004 \\
\hline$\Delta$ LBDC_NEG & 1.8094 & 0.8043 & 2.2497 & 0.0020 \\
\hline$\Delta$ LBDC_NEG(-1) & -1.0231 & 7.2411 & -0.1413 & 0.8886 \\
\hline$\Delta$ LGDPNeth & -1.8708 & 3.8944 & -0.4804 & 0.6346 \\
\hline LGDPNIG & -0.9982 & 0.1372 & -7.2785 & 0.0000 \\
\hline ECM(-1) & 0.2237 & 0.1857 & 1.2046 & 0.2375 \\
\hline B: Transportation & -0.0407 & 0.0136 & -2.9995 & 0.0071 \\
\hline TBTRNNI(-1) & -0.5033 & 0.2004 & -2.5111 & 0.0014 \\
\hline$\Delta$ LBDC_POS & 4.9153 & 1.1545 & 4.2574 & 0.0002 \\
\hline$\Delta$ LBDC_NEG & -1.7085 & 0.4928 & -3.4671 & 0.0649 \\
\hline$\Delta$ LGDPNeth & -0.7763 & 0.1461 & -5.3140 & 0.0000 \\
\hline LGDPNIG & -0.1155 & 0.1711 & -0.6754 & 0.5039 \\
\hline ECM(-1) & 0.1326 & 0.0445 & 2.9838 & 0.0076 \\
\hline C: Other Business Services & -0.3432 & 0.0881 & -3.8964 & 0.0011 \\
\hline$\Delta$ TBOTBSNI(-1) & -0.2144 & 0.3451 & -0.6212 & 0.5385 \\
\hline$\Delta$ LBDC_POS & 0.0969 & 0.3030 & 0.3199 & 0.7510 \\
\hline$\Delta$ LBDC_NEG & -1.1155 & 0.1595 & -6.9932 & 0.0000 \\
\hline$\Delta$ LGDPNeth
\end{tabular}

The positive and negative (current and first lag) of Bureau de change exchange rate (BDC) positively and significantly impacted on travels trade balance (TBTRVNN) asymmetrically. Also, an asymmetric relationship exists in the transportation (TBTRNNI) trade balance model. This is attributed to the positive and negative Bureau de change exchange rate (BDC) with a positive and significant impact.

This implies that if there is an increased inflow of foreign currency into Nigeria, this will increase the wealth of the citizens and the country at large. This will in turn improves the country's gross domestic product. Conversely, the other business services (TBOTBSNI) trade balance model observed an asymmetric 
relationship in the positive and negative Bureau de change exchange rate (BDC) but with a negative and significant impact. This infers that appreciation of the country's currency, the naira may adversely effects the other business services but not the travels and transportation sectors. The increase in Nigeria's income may support to enhance exports of Netherlands, while rise in Netherland's income could have negative effects on the services sectors. These findings were in consonance with Chesson et al. (2018), Bahmani-Oskooee and Hajilee (2011), Bahmani-Oskooee et al. (2006) and supported by the empirical findings of Bahmani-Oskooee and Arize (2020), Mahmood and Al-Khateeb (2017) who opined that devaluation confirms existence of J-curve after some lag and thus, the existence of asymmetric relationship between the services sectors and exchange rate in both the short- and long- run.

Table 9. NARDL Long-Run Results

\begin{tabular}{|l|c|c|c|c|}
\hline A: Travels & Coefficient & Std. Error & t-Statistic & Prob. \\
\hline C & 0.0613 & 0.5098 & 0.1203 & 0.4482 \\
\hline TBTRVNN(-1) & -1.0597 & 0.1737 & -6.0996 & 0.0000 \\
\hline$\Delta$ LBDC_POS) & -1.2101 & 0.3698 & -3.2721 & 0.0051 \\
\hline$\Delta$ LBDC_NEG(-1) & -0.7831 & 0.2106 & -3.7176 & 0.0019 \\
\hline$\Delta$ LGDPNeth & -0.9654 & 0.2800 & -3.448 & 0.0038 \\
\hline LRGDPNIG & -1.7654 & 0.7138 & -2.4732 & 0.0073 \\
\hline B: Transportation & -2.6474 & 1.8823 & -1.4064 & 0.1695 \\
\hline C & -0.7763 & 0.1857 & -4.1807 & 0.0002 \\
\hline TBTRNNI(-1) & -0.3907 & 0.1287 & -3.0350 & 0.0009 \\
\hline$\Delta$ LBDC_POS & -0.2232 & 0.0313 & -7.1358 & 0.0000 \\
\hline$\Delta$ LBDC_POS(-1) & -0.3033 & 0.0404 & -7.5021 & 0.0000 \\
\hline$\Delta$ LBDC_NEG & 4.9153 & 1.6642 & 2.9536 & 0.0046 \\
\hline$\Delta$ LGDPNeth & 0.2086 & 0.7100 & 0.2939 & 0.7708 \\
\hline$\Delta$ LGDPNeth(-1) & -1.7085 & 0.5375 & -3.1788 & 0.0017 \\
\hline LGDPNIG) & -0.6107 & 0.6398 & -2.7784 & 0.9614 \\
\hline LGDPNIG(-1) & 1.5923 & 0.8027 & 1.9836 & 0.0552 \\
\hline C: Other Business Services & -1.1155 & 0.1711 & -6.5204 & 0.0000 \\
\hline C & 0.3665 & 0.1345 & 0.7344 & 0.0087 \\
\hline$\Delta$ TBOTBSNI(-1) & -0.1432 & 0.0381 & -1.6258 & 0.0023 \\
\hline$\Delta$ LBDC_POS & -0.3451 & 0.1144 & -0.6212 & 0.0071 \\
\hline$\Delta$ LBDC_NEG & 0.3030 & 0.0969 & 0.3199 & 0.0057 \\
\hline$\Delta$ LGDPNeth & \multicolumn{5}{|l}{} \\
\hline LGDPNIG & \multicolumn{5}{|l|}{} \\
\hline
\end{tabular}

This will translate to a worsening of the country's gross domestic product. The real GDP of Netherlands and Nigeria negatively influenced travels and other business services. However, the variables were statistically insignificant, same scenario was observed in the transport model for Nigeria's GDP. This means that a contraction of GDP in both economies would worsen the travels, transportation and other business services balance in Nigeria. The real GDP of Nigeria positively influenced transportation balance but was also statistically insignificant. This implies that an increase in Nigeria's GDP would greatly improve transportation 
services balance, Bahmani-Oskooee and Arize (2020), Bahmani-Oskooee and Harvey (2017) and Mahmood and Al-Khateeb (2017) also elucidated a similar result. They also found asymmetric exchange rate and service sector behaviour was strongly evident in both the long run and short run, while it was only significant in the long run for Chesson et al. (2018).

The error correction term was properly signed as expected and the speed of adjustment was $99.8 \%, 77.6 \%$ and $111.5 \%$, respectively. This implies that travels, transportation and other business services trade balance adjust by $99.8 \%, 77.6 \%$ and $111.5 \%$, respectively to the changes in exchange rate in the previous period. Hence, the period it will take to completely adjustment to a given change in BDC is almost eight quarters for Travels and other business services model and twelve quarters for transportation model.

Haven ascertained the asymmetry presence in the Travels, Transportation and Other business services model, we present the long-run asymmetric dynamics as presented in Table 6. The first lag of travels, transportation and other business services negatively and significantly impacted on their current values. This implies that if their first lag increases by a percent, Travels, Transportation and Other business services will decrease by their respective coefficient.

Furthermore, the positive (POS) components of the main regressor variables in all the three models were statistically significant. However, it negatively influenced the behaviour of travels and transportation variables and positively influenced other business services in the long-run. For instance, a $1 \%$ rise in BDC_POS, BDC_NEG in Travels, would results in travels balance decreasing by $1.21 \%$ and $0.78 \%$, respectively in the long-run. Also, a per cent rise in first lag of travels, Netherlands and Nigeria's GDP, would translate to a significant decline in Nigeria's travels balance by $1.06 \%, 0.97 \%$ and $1.77 \%$, respectively. Given the long-run asymmetry in BDC, the result shows that a percentage increase in the exchange rate will result in an asymmetric fall to revenue accruable to Nigeria through travels. These findings were in line with the study by Bahmani-Oskooee and Fariditavana (2016) and Chui et al. (2010), on J-curve curve phenomenon and US trade imbalance and real exchange rate, respectively, and Chesson et al. (2018) for long run asymmetry only.

The Granger Causality test in Table 10 was implemented under the NARDL model. The variables in the model were assessed at both level and first difference in an ARDL context. The lag length criterion was automatically selected. The nonlinear autoregressive distributed lag model was evaluated using four lag and the result reveals the absence of autocorrelation. The result in Table 7 show three types of Granger causalities were examine, namely Short-run, long-run and strong NARDL causality test.

The result shows that all the variables in the short-run except LRGDPNIG were significant in the three models, for the long-run test all the variables were significant while for strong test, only the LBDC_POS and LBDC_NEG were significant for Travels, and except LRGDPNIG all other variables significant in the Transportation and Other Business Services Model. This confirms the existence of convergence of the system back to equilibrium position, which satisfies equations (2, 3 and 4). Furthermore, a mutual (short-run, long-run and 
strong) causality also exists between the selected macroeconomic variables, Travels, Transportation and Other Business Services balance which confirms the existence of bi-directional causality between the variables.

Table 10. NARDL Causality

\begin{tabular}{|l|c|c|c|c|c|c|}
\hline A: Travels \\
\hline A: Travel & Short-Run & p-value & Long- Run & p-value & Strong & p-value \\
\hline$\Delta$ LBDC_POS & 8.3631 & 0.0008 & 28.202 & 0.0000 & 7.9110 & 0.0049 \\
\hline$\Delta$ LBDC_NEG & 13.030 & 0.0003 & 28.202 & 0.0000 & 7.6804 & 0.0056 \\
\hline$\Delta$ LGDPNeth & 12.134 & 0.0004 & 28.202 & 0.0000 & 0.9056 & 0.3413 \\
\hline LGDPNIG & 0.0504 & 0.8223 & 28.202 & 0.0000 & 0.0008 & 0.9769 \\
\hline B: Transportation \\
\hline$\Delta$ LBDC_POS & 18.0472 & 0.0000 & 17.4781 & 0.0000 & 12.2029 & 0.0005 \\
\hline$\Delta$ LBDC_NEG & 8.2900 & 0.0002 & 17.4781 & 0.0000 & 32.6284 & 0.0000 \\
\hline$\Delta$ LGDPNeth & 3.4039 & 0.0650 & 17.4781 & 0.0000 & 4.4897 & 0.0341 \\
\hline LGDPNIG & 2.2561 & 0.1331 & 17.4781 & 0.0000 & 0.6501 & 0.4201 \\
\hline C: Other Business Services \\
\hline$\Delta$ LBDC_POS & 10.5393 & 0.0009 & 42.5162 & 0.0000 & 40.2401 & 0.0000 \\
\hline$\Delta$ LBDC_NEG & 12.6431 & 0.0003 & 42.5162 & 0.0000 & 34.0046 & 0.0000 \\
\hline$\Delta$ LGDPNeth & 10.3859 & 0.0012 & 42.5162 & 0.0000 & 6.0490 & 0.0139 \\
\hline LGDPNIG & 0.1023 & 0.7491 & 42.5162 & 0.0000 & 11.4234 & 0.0007 \\
\hline
\end{tabular}

To confirm the existence of asymmetry in our model, we carried out the Wald tests both in the long and the short-run. The Wald test null hypothesis for long-run symmetry was rejected and the alternative hypothesis accepted because the calculated F-statistic exceeds the upper critical bound value in all the cases (see Table 11).

Table 11. Wald Test

\begin{tabular}{|c|c|c|}
\hline \multicolumn{3}{|c|}{ A: Travels } \\
\hline Test & Statistics & Probability \\
\hline F-statistic & 155.7139 & 0.0000 \\
\hline \multicolumn{3}{|c|}{ B: Transportation } \\
\hline F-statistic & 4.1718 \\
\hline \multicolumn{3}{|c|}{ C: Other Business Services } \\
\hline F-statistic & 97.3019 & 0.0052 \\
\hline
\end{tabular}

We also test for the long-run multipliers effects for asymmetrical in the three models as presented in A, B and C of Figure 1. The upper and lower thinned dotted line represents the $95 \%$ confidence interval bound. The upper thick dashed black line represents the cumulative dynamics of Travels, Transportation and Other Business Services, respectively, with respect to a per cent rise (negative shock) in BDC while the lower thick solid black solid line denote the influence of a per cent positive shock (decrease) hitting BDC in Travels, Transportation and Other Business Services, respectively. 
Figure 3. Dynamic Multiplier Effects - Asymmetric LR \& Symmetric SR for a $1 \%$ Exchange Rate Shock on Travels, Transportation and Other Business Services

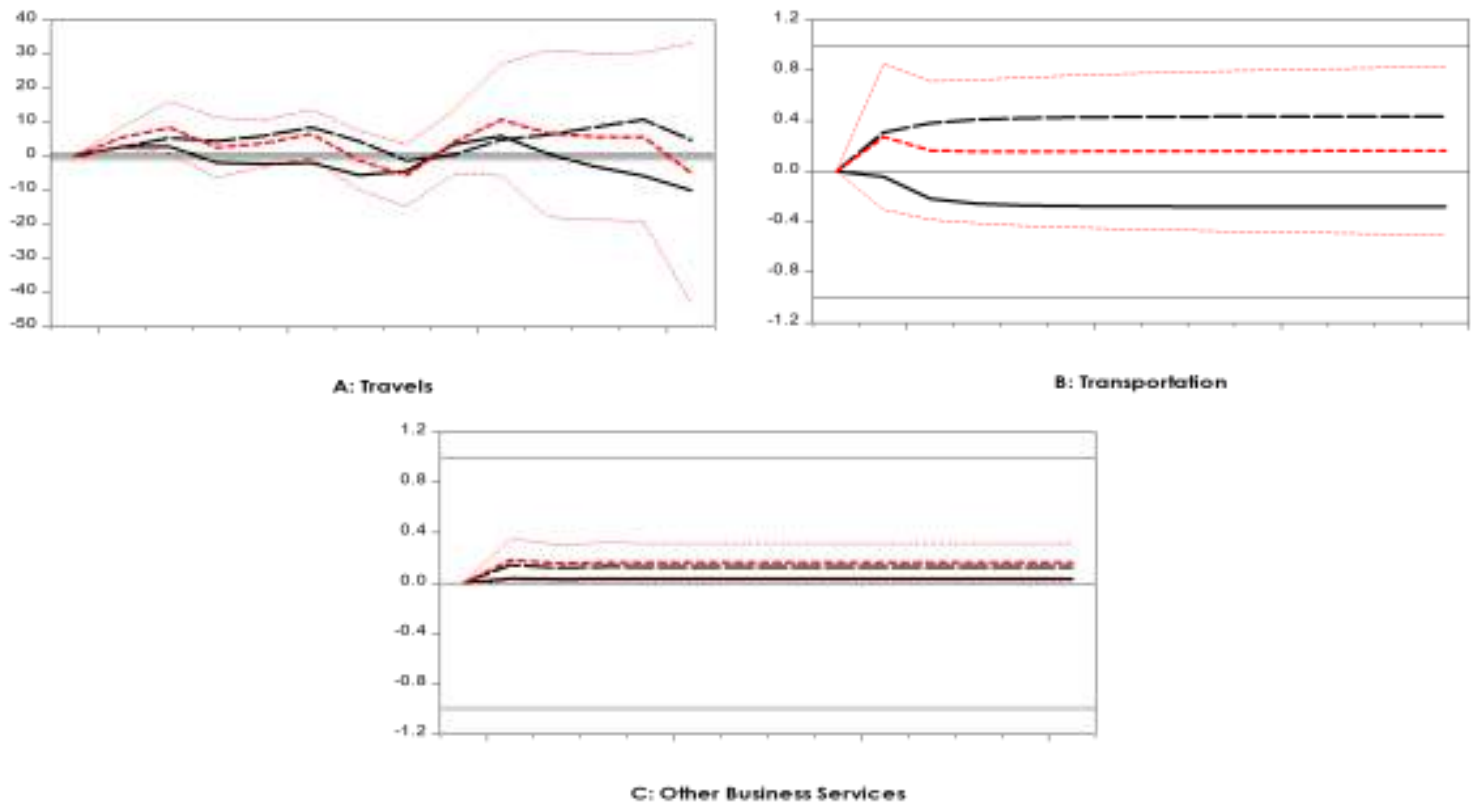

The red thick dotted line between the $95 \%$ confidence intervals provides the difference between a positive and negative reactions. Figure 1, illustrates that the negative component of BDC drives the asymmetry in relation to Travels, Transportation and Other Business Services, respectively. Accordingly, the reaction of Travels, Transportation and Other Business Services during periods when BDC depreciate (loss in value) surpasses that in periods of increase. However, from 2014Q1 to 2018Q4, the asymmetric response was driven mainly by the negative component in all three model.

In each model and each shock, Figure 3 (A, B and C), presents the dynamic multiplier for a positive shock (thick dashed line), for a negative shock (dotted thick line), and the difference between the positive and negative multipliers (dotted red line), along with its $95 \%$ confidence interval. Acceptance of long-run asymmetry means that zero do fall within the confidence interval in the long run.

\section{Conclusion}

Our paper employed the recent Shin et al. (2014) NARDL econometric methodology, to investigate the existence and nature of definite reactions of exchange rate for the period 2008Q1 to 2018Q4. Asymmetries in the adjustment of exchange rate were found in the three models. The study implemented a more flexible modelling approach that cautiously make a distinction concerning the short-run and the long- run performances, which allow one to resolve some mystifying evidence in extant literature and to explicate some obvious ambiguities.

The results reveal that the short-run adjustment in exchange rate in Nigeria's Transportation and Other Business Services is symmetric. The result also affirmed 
that in all the three NARDL estimates, our results indicated evidently that linearity do not apply in both the short- and long- run responses. It also proves that the negative non-linearity of exchange rate to Travels, Transportation and other Business Services changes is evident between Nigeria and Netherlands. A positive non-linearity with regard to exchange rate, characteristics in all three services sectors analyzed. We discovered "asymmetric asymmetry" the coexistence of a negative and positive non-linearity with regard to bureau de change exchange rate. Finally, the exchange rate depreciation pass in the disaggregated service balance increased larger in travels than that found in transportation and other business services.

The findings from this study can be extended in several perspectives. For example, the analysis of the presence a hysteretic effects in the exchange rate adjustment mechanism would be an interesting development for Nigeria. Furthermore, our investigation was based on only on two regimes (that is, the positive and negative regimes) of bureau de change exchange rate changes. This can be attributed to the low level of the impact of diversification changes, which are distributed differently. Since this is beyond the scope of this paper, we leave it future research.

\section{References}

Abogan OP, Akinola E, Baruwa O (2014) Non-oil export and economic growth in Nigeria. Journal of Research in Economics and International Finance 3(1): 1-11.

Aliyu SUR (2010) Exchange rate volatility and export trade in Nigeria: an empirical investigation. Applied Financial Economics 20(13): 1071-1084.

Aliyu JA, Tijjani MS (2015) Asymmetric cointegration between exchange rate and trade balance in Nigeria. Cogent Economics \& Finance 3(1): 1045213.

Atil A, Lahiani A, Nguyen DK (2014) Asymmetric and nonlinear pass- through of crude oil prices to gasoline and natural gas prices. Energy Policy 65(Feb): 567-573.

Babatunde MA (2016) Estimating price and income elasticities of trade in services in Nigeria. Ibadan Journal of the Social Sciences 14(1): 28-49.

Baggs J, Beaulieu E, Fung L (2010) Are service firms affected by exchange rate movements? Review of Income and Wealth 56(s1): 156-176.

Bahmani-Oskooee M, Economidou C, Goswami GG (2006) Bilateral J-curve between the UK vis-à-vis her major trading partners. Applied Economics 38(8): 879-888.

Bahmani-Oskooee M, Hajilee M (2011) Impact of exchange rate uncertainty on commodity trade between US and Sweden. Applied Economics 43(24): 3231-3251.

Bahmani-Oskooee M, Fariditavana H (2016) Nonlinear ARDL approach and the J-curve phenomenon. Open Economies Review 27(1): 51-70.

Bahmani-Oskooee M, Harvey $\mathrm{H}$ (2017) The asymmetric effects of exchange rate changes on the trade balance of Singapore. Global Economy Journal 17(4): 20170055.

Bahmani-Oskooee M, Arize AC (2020) On the asymmetric effects of exchange rate volatility on trade flows: evidence from Africa. Emerging Markets Finance and Trade 56(4): 913-939.

Bussiere M (2013) Exchange rate pass-through to trade prices: the role of nonlinearities and asymmetries. Oxford Bulletin of Economics and Statistics 75(5): 731-758.

Chesson A, Marilyn T, Haynes J (2018) Asymmetries in trade data-diving deeper into UK bilateral trade data. Office for National Statistics. 
Chui YB, Lee CC, Sun CH (2010) The US trade imbalance and real exchange rate: an application of the heterogeneous panel cointegration method. Economic Modelling 27(3): 705-716.

Dickson OO, Andrew U (2013) Exchange rate volatility effect on trade variations in Nigeria. Mediterranean Journal of Social Sciences 4(6): 401-406.

Imoughele LE, Ismaila M (2015) The impact of exchange rate on Nigeria non-oil exports. International Journal of Academic Research in Accounting, Finance and Management Sciences 5(1): 190-198.

Ketenci N, Uz I (2010) Trade in services: the elasticity approach for the case of Turkey. The International Trade Journal 24(3): 261-297.

Khan AJ, Azim P, Syed SH (2014) The impact of exchange rate volatility on trade: a panel study on Pakistan's trading partners. The Lahore Journal of Economics 19(1): 31-66.

Kilian L, Vigfusson RJ (2011) Are the responses of the U.S. economy asymmetric in energy price increases and decreases? Are responses of the U.S. economy asymmetric? Quantitative Economics 2(3): 419-453.

Mahmood H, Al-Khateeb TYT (2017) Testing asymmetrical effect of exchange rate on Saudi service sector trade: a non-linear ARDL approach. International Journal of Economics and Financial Issues 7(1): 73-77.

Mallick H (2012) Role of exchange rate on services and goods exports: a comparative empirical analysis. Washington DC: Centre for Global Development (CGD).

Moshirian F (2007) Trade in financial services. The World Economy 17(3): 347-364.

National Bureau of Statistics - NBS (2018) National Bureau of Statistics annual report. National Bureau of Statistics.

Ojede A (2015) Exchange rate shocks and US services and agricultural exports: which export sector is more affected? The International Trade Journal 29(3): 228-250.

Pattichis C (2012) Exchange rate effects on trade in services. Journal of Economic Studies 39(6): 34-45.

Prieto F, Sáez S, Goswami A (2011) The elusive road to service export diversification: the case of Chile. In Exporting Services: A Developing Countries Perspective, 309-360.

Rose AK, Yellen JL (1989) Is there a J-curve? Journal of Monetary Economics 24(1): 5368.

Shin Y, Yu B, Greenwood-Nimmo M (2014) Modelling asymmetric cointegration and dynamic multipliers in a nonlinear ARDL framework. In WC Horrace, RC Sickles (eds.), Festschrift in Honor of Peter Schmidt. New York: Springer Publishers. 